\title{
KELAS ONLINE MEMBUAT MAHASISWA STRESS
}

\author{
ONLINE CLAS IS STRESSFUL FOR STUDENTS
}

\section{Ilfia Waode}

Program Studi Psikologi, Fakultas Kedokteran, Universitas Lambung Mangkurat Jl. A. Yani Km 36 Banjarbaru Kalimantan Selatan, 70714, Indonesia.

Email : 2010914220003@mhs.ulm.ac.id No. Handphone :087841237340

\begin{abstract}
ABSTRAK
Sejak virus Covid - 19 dari Wuhan, China tiba di Indonesia. Sejak saat itu segalanya telah berubah, dan memiliki berbagai efek pada kita semua. Salah satu efeknya adalah perubahan gaya pembelajaran. Jurnal ini bertujuan untuk mengulas adanya stress akibat masa pandemi covid - 19 ini. Jurnal ini ditulis dengan metode kajian literatur dengan mengumpulkan beberapa data dan mengulasnya kembali pada jurnal ini. Data yang diperoleh berasal dari jurnal - jurnal, terlebih lagi pada jurnal dosen psikologi FK ULM. Saya mengulas jurnal tersebut dengan mencari beberapa penjelasan mengenai pendidikan, hal yang harus dimiliki oleh mahasiswa, faktor terjadinya stress, dan juga penanganan dari stress itu sendiri. Dan pada bagian akhirnya saya menarik kesimpulan mengenai stress yang terjadi pada mahasiswa karena pembelajaran online.
\end{abstract}

Kata Kunci : Mahasiswa, Stress, Kelas Online.

\begin{abstract}
Since the arrival of the Covid - 19 virus from Wuhan, China to Indonesia. And that's when everything changes, and causes various effects for all of us. One of the
\end{abstract}


Since the Covid - 19 virus from Wuhan, China arrived in Indonesia. Since then everything has changed, and has had various effects on all of us. One of the effects is a change in learning styles. This journal aims to review the stress caused by the Covid-19 pandemic. This journal is written using the literature review method by collecting some data and reviewing it in this journal. The data obtained came from journals, moreover from psychology lecturer journals FK ULM. I reviewed the journal by looking for some explanations about education, what students should have, factors for stress, and also the handling of stress itself. And in the end I draw a conclusion about the stress that occurs in students due to online class.

Keywords: Students, Stress, Online Class.

\section{PENDAHULUAN}

Sudah beberapa bulan ini Indonesia dilanda oleh virus mematikan yaitu Covid - 19. Covid 19 dapat menyebar melalui banyak cara, salah satunya melalui udara, makanya kita diharuskan memakai masker. Virus ini telah memakan banyak korban tanpa memandang umur dan status dari seseorang.

Untuk meanggulangi virus ini agar tidak lebih marak penyebarannya ,pemerintah mengeluarkan beberapa perturan yang harus diikuti oleh masyarakat Indonesia yaitu PSBB atau Pembatasan Sosial Berskala Besar, jadi para masyarakat dilarang untuk keluar rumah dalam beberapa waktu. Untuk para pekerja kantoran, mereka bekerja melalui online. Begitu juga bagi para pelajar tingkat dasar hingga tingkat akhir dan juga para mahasiswa.

Perkuliahan pada awal tahun 2020 ini sangatlah berbeda dengan sebelumnya. Virus Covid-19 yang telah menyebar ini menjadikan kuliah dilaksanakan secara online dan tidak tau kapan akan berakhir. Kuliah online ini pada awalnya sangat membuat para mahasiswa merasa senang, sebab para mahasiswa tidak perlu bangun subuh untuk bersiap kuliah. Cukup bangun beberapa menit sebelum kuliah, tidak perlu mandi, tidak perlu memakai pakaian yang 
rapi, adapun para mahasiswa juga dapat kuliah sambil rebahan di atas tempat tidurnya masing masing. Dan, yang paling membuat senang, para mahasiswa dapat lebih fokus dengan pemebelajaran karena tidak ada orang banyak disekitarnya [1]. Itu hanyalah awalnya saja.

Namun setelah dijalani beberapa minggu selanjutnya semuanya tiba -tiba berubah . Para mahasiswa terbebani oleh pemikiran dan merasa terus santai karena dirumah jadi suka ber malasan. Yang dimana dosen memeberikan tugas tidak langsung dikerjakan atau suka menunda. Yang mengakibatkan, pengerjaan laporan tersebut terburuburu bahkan ada yang melakukannya secara SKS atau Sistem Kebut Semalam [1].

Tingkat stress mahasiswa semakin melonjak akhir - akhir ini, tetapi memang sebenarnya sebelum adanya virus ini mahasiwa juga mengalami stress akibat adanya ketentuan kelulusan yang berasal dari universitas masing - masing yang harus di ikuti oleh para mahasiswa yang sedang belajar di universitas tersebut. Tetapi saat adanya virus, mahasiswa semakin merasa stress karena tugas yang diberikan oleh dosen tidak kunjung henti, dalam sehari misalkan ada tiga mata kuliah dan ketiga mata kuliah tersebut sama - sama memberi tugas yang deadlinenya pun sama dengan jenis tugas yang pengerjaannya memerlukan waktu yang lama, beberapa dosen yang memberikan tugas seperti itu kebanyakan berpikir mahasiswa itu kuliahnya dirumah pasti ia mempunyai banyak waktu untuk mengerjakannya. Padahal mahasiswa pun butuh istirahat walaupun perkuliahan diadakan secara daring dan dapat dilakukan dirumah masing - masing.

Dapat dikatakan hal ini dapat membuat santai, tetapi hal ini juga dapat membuat gangguan pada psikologis masyarakat yang disebabkan penyebaran berita belakangan ini, terutama berita tentang maraknya korban Coivd - 19, dan itu membuat semua masyarakat merasa ketakutan. [1].

\section{METODE PENELITIAN}


Jurnal ini ditulis Writing Theory (EWT) : "Tulislah menggunakan sebuah pendekatan apa yang ada di pikiran bukan kajian literatur atau metode pustaka memikirkan apa yang akan ditulis" yang terdiri dari beberapa bagian pendahuluan, metode penelitian, hasil dan pembahasan, kesimpulan, serta daftar pustaka [2]. Tujuan dari metode ini adalah untuk menjadi dasar teori yang kita angkat, selain itu dapat uga digunakan sebagai kesimpulan dan berguna untuk penilaian suatu topic tertentu [2].

Metode ini menggunakan cara pengumpulan beberapa data. Data data yang sudah dikumpulkan itu dibaca terlebih dahulu satu persatu lalu dipilah dan dipilih data yang sesuai dengan masalah yang ingin saya angkat, setelah itu saya kutip data yang sudah sesuai ke dalam jurnal saya. Data yang saya ambil berasal dari jurnal - jurnal penelitian yang dapat di akses melalui google scholar terutama jurnal dosen - dosen Psikologi FK ULM.

Selain itu di dalam jurnal ini saya menuliskan beberapa kalimat yang berasal dari yang saya rasakan dan pemikiran saya sendiri. Seperti lontaran yang dikatakan ala Ersis [3]. Karena itulah saya berani menuliskan apa yang saya pikirkan dan apa yang saya rasakan ke dalam jurnal ini.

\section{HASIL DAN PEMBAHASAN}

Mahasiswa merupakan salah satu komponen yang saling mempengaruhi untuk suatu universitas. Mahasiswa juga memiliki fungsi dasar yang berguna untuk mempelajari dan menemukan sebuah teori - teori baru dari sebuah ilmu pengetahuan dan juga berguna untuk memberikan suatu perubahan yang lebih baik melalui kecerdasannya dalam proses pembelajaran tersebut.

Proses belajar di universitas dan sekolah sebelumnya seperti SD / SMP / SMA sangatlah berbeda jauh. Di universitas ini mahasiswa dituntut untuk dapat mempelajari dan menganalisis permasalahan dalam studinya. Pembelajaran yang efektif dapat memenuhi kebutuhan mahasiswa. 
Seorang mahasiswa haruslah memiliki flow, agar ia dapat berkonsentrasi dan juga fokus ketika belajar di kelas, serta menikmati setiap proses belajar yang ia lakukan [4]. Selain itu mahasiswa harus memiliki kesadran diri, karena kesadaran diri adalah kemampuan untuk memilah berbagai perasaan dan mampu mengenali atau memahami apa yang kita rasakan dan dapat pula memahmi penyebab atau faktor apa yang menimbulkan perasaa tersebut, serta pengaruh perilaku masing masing orang (Nihayatus,2017) [5]. Dan juga dengan kesaddaran diri para mahasiswa dapat berguna untuk mencapai tujuan dari suatu pendidikan.

Salah satu stress yang biasa dialami mahasiswa yaitu stress akademik atau tekanan akademik. Stress akademik atau tekanan akademik mengacu kepada tekanan yang berkaitan dengan kegiatan pendidikan, yang terjadi pada kegiatan ini timbul karena adanya tuntutan yang timbul saat sesorang mengenyam pendidikan, dan ketika sesorang merasa ggugup secara emosional yang disebabkan tidak dapat emenuhi kebutuhan belajarnya [6].

Apalagi para mahasiswa baru, mereka masih berada di awal masa peralihan dari masa remaja menuju pendewasaan, yang dimana sering disebut dengan masa bermasalah[7]. Pada masa inilah sedang banyak banyaknya masalah yang terjadi dan harus diselesaikan secara masing masing karena tini merupakan proses peralihan dari remaja ke pendewasaan.

Mahasiswa juga perlu memiliki pemikiran yang kritis, karena berpikir kritis merupakan proses yang memiliki tujuan untuk membuat suatu keputusan yang tepat tentang keyakinan kita dan apa yang kita lakukan. Dalam hal ini, mahasiswa diharuskan bertanggung jawab atas keputusan yang akan diambil. Keputusan tersebut haruslah masuk akal dan laayak untuk dikerjakan [8].

Karena adanya sebuah tuntutan itu, tidak sedikit dari mahasiswa mengalami stress akibat perkuliahan. Saat perkulihan offline mahasiswa juga mengalami stress, 
seperti stress akibat adanya ujian yang full, prestasi seorang mahasiswa kurang di kampus, dan juga dari keketatnya peraturan di kampus [9]. Apa lagi dimasa pandemi Covid - 19 ini, tidak menutup kemungkinan terjadinya peningkatan stress pada mahasiswa.

Faktor yang menyebabkan meningkatnya stress pada mahasiswa saat belajar daring disebabkan oleh banyaknya tugas pembelajaran yang diberikan oleh dosen, merasa bosan selalu dirumah dan karena tidak ada interaksi langsung antar individu, tidak dapat bertemu dengan teman lainnya, adanya operuahan suasana pembelajaran dari yang offline menjadi online, terbatasanya kuota, dan adanya gejala pada jaringan [10]. Hal tersebutlah yang menjadi alasan peningkatan stress yang dialami oleh para mahasiswa.

Dalam menghadapi situasi yang dapat membuat stress dan penuh akan tekanan seperti ini, para mahasiswa perlu memiliki kesiapan untuk beradaptasi dengan kondisi tersebut, terutama saat memasuki dunia perkulihan [11]. Tetapi ada beberapa cara yang dapat mengurangi para mahasiswa stress karena perkuliahan secara daring seperti ber istirahat saat tidak ada tugas dan jadwal perkuliahan, memulai untuk berolahraga, saat berolahraga para mahasiswa dapat menyesuaikan dengan jadwal kuliah yang kosong dan untuk durasi berolahraga harus sesuai dengan ketahanan tubuh masing - masing. Nah untuk para mahsiswa yang suka memasak dapat mencoba beberapa resep baru yang banyak beredar di sosial media. Dan saat waktu luang dapat melakukan hobinya, contoh hobi yang sering dimiliki oleh para mahasiswa adalah menonton film atau series yang ia sukai.

\section{KESIMPULAN}

Tingkat stress mahasiswa semakin melonjak akhir- akhir ini, tetapi memang seenarnya sebelum adanya virus Covid - 19 ini, mahasiswa juga mengalami stress akibat adanya ketentuan kelulusan yang berasal dari universitas masing masing yang harus di ikuti oleh para mahasiswa yang sedang belajar di sebuah universitas. 
Tetapi saat adanya virus ini justru lebih banyak mahasiswa yang mengalami stress yang diakibatkan oleh banyaknya tugas pembelajaran yang di berikan oleh dosen, merasa bosan beradda dirumah, terbatasnya kuota internet dan kendala jaringan yang bukan kehendak para mahasiswa, dan sebagainya. Dan dalam menghadapi situasi yang dapat membuat stress itu kita perlukan kesiapan untuk dapat bertahan dan menyesuaikan diri dengan kondisi saat ini.

\section{DAFTAR PUSTAKA}

[1] Abbas, E. W., \& Erlyani, N. (2020). Menulis di Kala Badai Covid-19.

[2] Shadiqi, M. A., Hariati, R., Hasan, K. F. A., I'anah, N., \& Al Istiqomah, W. (2020). Panic buying pada pandemi COVID-19: Telaah literatur dari perspektif psikologi. Jurnal Psikologi Sosial.

[3] WARMANSYAH ABBAS, E. R. S. I. S. (2020). Menulis di Era Covid-19: Memanage Trauma Psikologis Menghindari Psikosomatis. Menulis di Era
Covid-19: Memanage Trauma Psikologis Menghindari Psikosomatis.

[4] Primasari, L. E., Mayangsari, M. D., \& Zwagery, R. V. (2020). HUBUNGAN RESILIENSI DENGAN FLOW AKADEMIK PADA SISWA DI DAERAH LAHAN GAMBUT. Kognisia prodi Psikologi FK ULM, 2(1), 99-104.

[5] Astuti, J. P., Mayangsari, M. D., \& Zwagery, R. V. (2020). HUBUNGAN KESADARAN DIRI DENGAN FLOW AKADEMIK PADA SISWA DI DAERAH LAHAN GAMBUT. Kognisia prodi Psikologi FK ULM, 2(2), 68-74.

[6] Putri, C. P., Mayangsari, M. D., \& Rusli, R. (2020). PENGARUH STRES AKADEMIK TERHADAP ACADEMIC HELP SEEKING PADA MAHASISWA PSIKOLOGI UNLAM DENGAN INDEKS PRESTASI KUMULATIF RENDAH. Kognisia prodi Psikologi FK ULM, 1(2), 28-37.

[7] Afnan, A., Fauzia, R., \& Tanau, M. U. (2020). HUBUNGAN 
8 Jurnal Edukasi, Volume 1 Nomor 1, November 2020

EFIKASI DIRI DENGAN

STRESS PADA MAHASISWA

YANG BERADA DALAM

FASE QUARTER LIFE

CRISIS. Jurnal Kognisia: Jurnal

Mahasiswa

Psikologi

Online, 3(1), 23-29.

[8] Arman, J., Hidayatullah, M. S., \&

Mayangsari, M. D. (2020).

PERANAN KECERDASAN

ADVERSITAS TERHADAP

KEMAMPUAN BERPIKIR

KRITIS PADA MAHASISWA

YANG AKTIF ORGANISASI DI

FAKULTAS KEDOKTERAN

UNIVERSITAS LAMBUNG

MANGKURAT. Kognisia prodi

Psikologi FK ULM, 2(1), 42-50.

[9] Khairul, R., Mayangsari, M. D., \&

Rusli, R. (2020). EFEKTIVITAS

SENAM ZUMBA TERHADAP

PENURUNAN

TINGKAT

STRES AKADEMIK PADA

REMAJA DI SMP DARUL

HIJRAH PUTRI. Kognisia prodi

Psikologi FK ULM, 2(1), 114121.

[10] Livana, P. H., Mubin, M. F., \& Basthomi, Y. (2020). " Learning Task" Attributable to Students' Stress During the Pandemic
Covid-19. Jurnal Ilmu

Keperawatan Jiwa, 3(2), 203-

208.

[11] Eunike, A., Mayangsari, M. D., \& Hidayatullah, M. S. (2020). HUBUNGAN ANTARA KEMATANGAN

VOKASIONAL DENGAN HARDINESS PADA SISWA $\begin{array}{lll}\text { SMK } & \text { NEGERI } & 1\end{array}$ MARTAPURA. Kognisia prodi Psikologi FK ULM, 2(2), 49-54. 